\title{
EFEKTIFITAS PASAL 303 BIS KUHP DALAM MENANGGULANGI TINDAK PIDANA PERJUDIAN SEBAGAI PENYAKIT MASYARAKAT
}

\author{
oleh: \\ Dini Ramdania
}

\begin{abstract}
Abstrak
Perjudian adalah salah satu penyakit masyarakat yang dapat menimbulkan kejahatan lainnya apabila dibiarkan. Ternyata pemberantasan perjudian ini tidaklah mudah, hal ini dapat dilihat dari berbagai macam upaya pihak Kepolisian untuk memberantas penyakit masayarakat tersebut, tetapi dari tahun ke tahun pelaku perjudian tetap ada dan bahkan kadang menjadi melonjak tajam apabila ada momen tertentu seperti olah raga dan lainnya yang dimanfaatkan untuk kepentingan sekelompok orang. Penerapan Pasal 303 Bis terhadap para pelaku Judi telah dilaksanakan walau tidak semua para pelaku judi di pidana karena dari keterangan yang diperoleh dan berkasnya yang di kenakan Pasal 303 Bis adalah para penjual atau pengepulnya sedangkan para pemain hanya diberikan sanksi kurungan yang kemudian diberi peringatan kemudian dilepaskan. Hal ini mungkin menjadi salah satu penyebab kenapa judi sulit untuk di tumpas sampai pada lingkungan terkecil.Padahal dalam UU No. 7 tahun 1974 tentang Penertiban Perjudian dimana dalam Pasal 1 disebutkan bahwa semua tindak pidana perjudian adalah kejahatan dan adanya sanksi pidana yang diperberat dalam Pasal 2 UU No.7 tahun 1974 tentang Penertiban Perjudian ini, maka seharusnya seluruh pelaku tindak pidana perjudian diterapkan Pasal 303 KUHP dan juga diterapkan Pasal 303 bis dengan ancaman pidana yang lebih berat. Hal ini dilakukan mengingat akibat dari permainan judi tersebut sangat merusak hidup dan penghidupan manusia pada saat ini dan masa yang akan datang. Sedikitnya pelaku tindak pidana perjudian yang dikenakan hukuman Pasal 303 Bis juga sangat berpengaruh pada peredaran judi itu sendiri. Banyak faktor yang menyebabkan pelaku tindak pidana judi tidak dipidana salah satu alasannya adalah karena tindak pidana perjudian adalah tindak pidana ringan. Pemerintah disini harus memikirkan solusi yang lain untuk menanggulangi tindak pidana perjudian yaitu dengan adanya restoraktif justise, yaitu dimungkinkannya hukuman atau sanksi lain bagi para pelaku tindak pidana perjudian seperti denda dan sanksi sosial.
\end{abstract}

Kata kunci : Judi , penyakit masyarakat, sanksi hukum

\section{PENDAHULUAN}

Perjudian adalah pertaruhan dengan sengaja yaitu mempertaruhkan suatu nilai atau sesuatu yang dianggap bernilai dengan menyadari adanya resiko dan harapan-harapan tertentu pada peristiwa-peristiwa permainan, pertandingan, perlombaan dan kejadian-kejadian yang tidak atau belum pasti hasilnya.

Kasus-kasus perjudian dengan omzet jutaan sampai dengan miliaran rupiah terjadi di daerah Jakarta, Bandung, Medan, Surabaya dan sebagainya yang berhasil di gerebek oleh pihak kepolisian merupakan contoh nyata terjadinya perbuatan yang di larang olehUndangUndang yang sempat diekspos oleh media masa sampai saat ini. Perbuatan mereka jelas sebagai kejahatan dalam tataran hukum positif. Anehnya lagi, siapa dalang utama yang berdiri di balik usaha perjudian itu belum berhasil di ungkapkan oleh pihak kepolisian. Masyarakat menganggap bahwa kejahataan itu sangat sulit untuk di berantas. Keadaan ini sering menjadi perbincangan hangat warga masyarakat awam seperti di warung kopi pinggir jalan bahwa dari 
kejahatan perjudian tidak pernah tertangkap atau kebal hukum. Buktinya, mereka ini jarang sekali di ajukan ke depan meja hijau oleh aparat penegak hukum. ${ }^{1}$

Undang-Undang Hukum Pidana Pasal 303 Ayat 3, Perjudian itu dinyatakan sebagian berikut. "Main judi berarti tiap-tiap permainan yang kemungkinannya akan menang, pada umumnya tergantung pada untung-untungan saja, juga kalau kemungkinan bertambah besar, karena pemain lebih pandai atau lebih cakap. Main judi mengandung segala pertaruhan tentang keputusan perlombaan atau pemain lain yang tidak tiadakan oleh mereka yang turut berlomba atau main itu, demikian juga segala pertaruhan lainnya".

Pidana atau hukuman merupakan hal terpenting dalam hukum pidana atau hukuman merupakan hal terpenting dalam hukum pidana. Namun hukum pidana menunjukan secara harfiah bahwa itu berarti hukum tentang pidana. Demikian sehingga J. Van Kan menyebut hukum pidana pada hakikatnya merupakan hukum sanksi. J. Van Kan mengatakan mengancam pelanggaran dengan nestapa istimewa. Ia mengancam pidana. Pidana dapat berupa pidana mati, potongan anggota badan, cambuk, perampasan kemerdekaan dan pernyataan tidak hormat. Jenis pidana tercantum di dalam Pasal 10 KUHP. Jenis pidana ini berlaku juga bagi delik yang tercantum di luar KUHP, kecuali ketentuan Undang-Undang itu menyimpang (Pasal 103 KUHP).

Jika ada individu yang bekerja dianggap "bersalah" sebab ia melakukan perjudian yang dianggap sebagai kejahatan, maka hak melakukan pekerjaan tadi bisa dicabut (individu di keluarkan dari pekerjaannya). Selanjutnya, masyarakat umum menganggap tindak judi itu sebagai tingkah laku asusila, disebabkan oleh ekses-eksesnya yang buruk dan merugikan. Khususnya merugikan diri sendiri dan keluarganya, karena segenap harta kekayaan, bahkan kadangkala juga anak dan istri habis dipertaruhkan di meja judi. Juga oleh nafsu berjudi orang berani menipu, mencuri, korupsi, merampok, dan membunuh orang lain untuk mendapatkan uang guna bermain judi. ${ }^{2}$

Dali Mutiara menebutkan 3 , dalam KUHP sebagai berikut :"Permainan judi ini harus di artikan dengan arti yang luas, juga termasuk segala pertaruhan tentang kalah-menangnya suatu pacuan kuda atau pertandingan lain, atau segala pertaruhan dalam perlombaanperlombaan yang di adakan antara 2 orang yang tidak ikut sendiri dalam perlombaanperlombaan itu, misalnya totalistor, dan lain-lain.

Perspektif hukum perjudian merupakan salah satu tindak pidana yang meresahkan masyarakat sehubungan dengan itu, dalam Pasal 1Undang-Undang Nomor 7 Tahun 1974 Tentang Penertiban Perjudian dinyatakan bahwa semua tindak pidana perjudian sebagai kejahatan.

Perjudian adalah salah satu penyakit masyarakat yang menunggal dengan kejahatan, yang dalam proses sejarah dari generasi ke generasi ternyata tidak mudah di berantas. Oleh karena itu perlu di usahakan agar masyarakat menjauhi melakukan perjudian terbatas pada lingkungan sekecil-kecilnya. Dan terhindarnya lebih parah untuk pada akhirnya dapat berhenti melakukan perjudian. Karena ancaman hukuman sekarang yang berlaku ternyata sudah tidak sesuai lagi dan tidak membuat pelakunya mempunyai efek jera terhadap tindak pidana perjudian yang ia lakukan. Jadi bagaimana seharusnya tindakan dari Pemerintah untuk memberantas perjudian ini?

\footnotetext{
${ }^{1}$ Teguh Sulistia, Aria Zurnetti, Hukum Pidana Horizon Baru Pasca Reforasi, PT. Raja Grafindo Persada, Jakarta, 2011, hlm 37

${ }^{2}$ Kartini Kartono, Patologi sosial , PT. Raja Grafindo Persada, Jakarta, 2015, hlm. 58

${ }^{3}$ Dalil Mutiara, Tafsir KUHP, Bintang Indonesia, Jakarta 1962, hlm. 203
} 


\section{TINJAUAN PUSTAKA}

\section{Teori Efektivitas}

Efektivitas hukum adalah merupakan suatu teori yang membahas mengenai ketaatan manusia ataum masyarakat terhadap hukum yang berlaku. Jika suatu aturan hukum ditaati maka dapat dikatakan bahwa aturan hukum tersebut efektif. Taat kepada hukum menurut H.C. Kelman dalam bukunya Satjipto Rahardjo mengatakan dapat dilihat dari 3 (tiga) faktor, yaitu :4)

1) Compliance (taat kepada sanksi);

2) Identification ( taat karena menjaga hubungan baik);

3) Internalization (taat karena nilai intrinsik yang dianut).

Efektif atau tidaknya suatu aturan hukum dapat dilihat dari seberapa besar masyarakat mentaati aturan hukum tersebut dan tergantung dari kepentingannya, jika masyarakat taat hukum karena kepentingan Compliance (taat karena sanksi ), identification (taat karena menjaga hubungan baik) maka derajat ketaatannya sangat rendah dan dapat disimpulkan bahwa suatu aturan hukum tidak efektif di masyarakat tersebut. Tetapi apabila ketaatan masyarakat karena internalization (taat karena nilai intrinsic yang dianut ) maka dapat diartikan bahwa masyarakat tersebut sudah taat hukum dan aturan hukum tersebut sangat efektif. ${ }^{5)}$

Achmad Ali mengatakan : Faktor yang mempengaruhi efektivitas hukum dan perundang-undangan adalah professional dan optimal, pelaksanaan wewenang, dan fungsi dari penegak hukum, baik dalam menjalankan tugas yang dibebankan kepada mereka maupun dalam menegakan hukum dan undang-undang. ${ }^{6}$

Bekerjanya undang-undang dapat dilihat dari dua persfektif, antara lain :7)

a) Perspektif organisatoris, memandang undang-undang sebagai institusi yang ditinjau dari ciri-cirinya. Di dalam perspektif ini tidak terlalu memperhatikan pribadi-pribadi yang pergaulan hidupnya diatur oleh hukum atau perundang-undangan.

b) Persfektif individu ketaatan, yang lebih berfokus pada segi individu atu pribadi dimana pergaulan hidupnya diatur oleh perundang-undangan. Fokus perspektif individu adala kepada masyarakat sebagai kumpulan pribadi-pribadi. Faktor kepentingan yang menyebabkan orang taat atau tidak taat terhadap undang-undang, dengan kata lain pola-pola perilaku masyarakat yang banyak mempengaruhi efektifitas perundang-undangan.

Efektivitas hukum dalam tindakan atau realita hukum dapat diketahui apabila seseorang menyatakan bahwa suatu kaidah hukum berhasil atau gagal mencapai tujuannya, maka hal itu biasanya diketahui apakah pengaruhnya berhasil mengatur sikap tindak atau perilaku tertentu sehingga sesuai dengan tujuannya atau tidak. Efektivitas hukum artinya efektivitas hukum akan disoroti dari tujuan yang ingin dicapai, yakni efektivitas hukum. Salah satu upaya yang biasanya dilakukan agar supaya masyarakat mematuhi kaidah hukum adalah dengan mencantumkan sanksi-sanksinya. Sanksi-sanksi tersebut bisa berupa sanksi negative atau sanksi positif, yang maksudnya adalah menimbulkan rangsangan agar manusia tidak melakukan tindakan tercela atau melakukan tindakan terpuji. ${ }^{8)}$

\footnotetext{
4) Satjipto Rahardjo, Ilmu Hukum, Citra Aditya Bakti, Bandung, 2000, hlm.20.

5) Ibid

6) Achmad Ali, Kesadaran Hukum Masyarakat Dan Pengaruhnya Bagi Efektivitas Perkembangan Hukum, Sinar Baru, Bandung, 2009, hlm.4.

7) Ibid

8) Ibid
} 
Diperlukan kondisi-kondisi tertentu yang harus dipenuhi agar hukum mempunyai pengaruh terhadap sikap tindak atau perilaku manusia. Kondisi-kondisi yang harus ada adalah antara lain bahwa hukum harus dapat dikomunikasikan. Komunikasi hukum lebih banyak tertuju pada sikap, oleh karena sikap merupakan suatu kesiapan mental sehingga seseorang mempunyai kecenderungan untuk memberikan pandangan yang baik atau buruk yang kemudian terwujud dalam perilaku nyata. ${ }^{9)}$

Kesadaran hukum dalam masyarakat belumlah merupakan proses sekali jadi melainkan suatu rangkain proses yang terjadi tahap demi tahap kesadaran hukum masyarakat sangat berpengaruh terhadap ketaatan terhadap hukum dan efektivitas hukum dalam masyarakat, baik secara langsung maupun tidak langsung, dalam masyarakat maju orang yang patuh pada hukum karena memang jiwanya sadar bahwa mereka membutuhkan hukum dan hukum itu bertujuan baik untuk mengatur masyarakat secara baik, benar dan adil. Sebaliknya dalam masyarakat tradisional kesadaran hukum masyarakat berpengaruh secara tidak langsung kepada kepatuhan hukum.

\section{Perjudian Sebagai Penyakit Masyarakat}

Pasal 1 ayat (1) huruf c UU Kepolisan Negara tersebut, salah satu wewenang yang di berikan kepada polisi adalah mencegah dan menanggulangi timbulnya penyakit masyarakat. Yang di maksud dengan penyakit masyarakat disini adalah antara lain pengemisan dan gelandangan, pelacuran, perjudian, penyalah gunaan obat dan narkotika, pemabukan, perdagangan manusia, penghipusan/praktik lintah darat, dan pungutan liar. Dari uraian tersebut dapat di lihat bahwa polisi berperan dalam mencegah dan menanggulangi tindak pidana perjudian yang di anggap sebagai penyakit masyarakat yang dapat mengganggu ketertiban masyarakat. Dalam menjalankan tugas-tugas tersebut, Pejabat Kepolisian Negara Republik Indonesia senantiasa bertindak berdasarkan norma hukum dan juga norma agama, kesopanan, kesusilaan, serta menjungjung tinggi HAM.

Perjudian merupakan kejahatan dan oleh sebab itu praktiknya perlu di cegah dan di tanggulangi demi tegaknya hukum, dan upaya atau kebijakan yang dapat di lakukan untuk mencegah dan menanggulangi kejahatan tersebut adalah melalui upaya atau kebijakan kriminal.

\section{Tindak Pidana Perjudian}

KUHP memberikan definisi main judi yang terdapat dalam Pasal 303 ayat (3) yaitu permainan judi adalah tiap-tiap permainan dimana pada umumnya kemungkinan mendapat untung tergantung pada peruntungan belaka, juga karena permainannya lebih terlatih atau lebih mahir. Di situ termasuk segala pertaruhan tentang keputusan, perlombaan atau permainan lain-lainnya yang tidak diadakan antara mereka yang turut berlomba atau bermain, demikian juga segala pertaruhan lainnya. Yang dalam penjelasan pasal tersebut menyatakan bahwa tidak termasuk permainan judi atau perjudian adalah permainan tertentu yang biasa dipergunakan untuk hiburan. Apakah bermain itu untuk hiburan ataukah untuk mendapatkan keuntungan tergantung pada besar kecilnya taruhan. Bila taruhannya kecil sehingga bermain semalam suntuk keuntungan atau kekalahan tidak berarti maka permainan ini dapat dikatakan untuk hiburan atau untuk mengisi waktu.

Pengadilan Tinggi Medan dalam putusannya No.62/1956 tanggal 23 Juli 1957 menyatakan bahwa unsur-unsur penting main judi adalah :10)

a. Aktivitas pada kedua belah pihak, baik pada bandar maupun pada peserta, dari istilah itu "permainan",

\footnotetext{
9) Soerjono Soekamto, Sosiologi Suatu Pengantar, Citra Aditya Bakti, Bandung, 1991, hlm.29

10) Soebroto Brotodiredjo, Pengantar Hukum Kepolisian Umum Di Indonesia, Yuseha, 1997, Bandung, hlm. 65 .
} 
b. Aktivitas kedua belah pihak dilakukan pada tempat tertentu pada waktu yang bersamaan ataupun yang agak bersamaan,

c. Pada satu kali main, mungkin yang menang lebih dari seorang peserta .

Sartono Mukadis dalam bukunya Soebroto Brotodiredjo menyatakan bahwa penjudi dan orang yang gampang terjerumus ke dunia judi adalah $:^{11)}$

(1) Orang yang ingin cepat berhasil dengan cara yang mudah;

(2) Menganut sistem nilai yang tidak jelas; dan

(3) Orang yang kepribadiannya.

Perjudian dilakukan dengan cara $:^{12)}$

1) Menebak kata atau beberapa angka pada suatu keputusan undian (judi buntut);

2) Menebak satu atau beberapa angka pada suatu alat yang diputar (rolett) atau yang dijatuhkan (dadu) atau yang dibuka setelah ditutup atau disimpan ( gapleh);

3) Menebak hasil pertandingan atau perlombaan (sepak bola atau balap kuda);

4) Memutar mesin judi tanpa menebak atau cara lain dengan taruhan uang atau barang.

Ada 3 macam judi buntut (menebak angka terakhir dari nomor suatu lotere yang keluar sebagai pemenang) menurut R. Rachmat Boedioetomo, ialah :13)

(a) Buntutan, bertaruh atas dua angka terakhir dan bila tepat mendapatkan 70 kali taruhannya;

(b) Kop, bertaruh atas 3 angka terakhir dengan mendapatkan 450 kali taruhan;

(c) Hoki, bertaruh atas 4 angka terakhir dengan mendapatkan 4500 kali taruhan.

\section{Pertanggungjawaban Pidana}

Ajaran tentang pertanggungjawaban pidana adalah mengenai keadaan jiwa/batin seseorang yang sehat dan normal ketika melakukan pidana. Selain itu pertanggungjawaban pidana atau kemampuan bertanggung jawab meliputi tiga hal, yaitu :

a. tentang keadaan jiwa/bathin seseorang yang sakit;

b. tentang keadaan jiwa/bathin seseorang yang umurnya sangat muda, sehingga keadaan jiwanya belum matang;

c. tentang keadaan jiwa/bathin seseorang yang organ bathinnya baik akan tetapi fungsi batinnya mendapat gangguan, sehingga tidak dapat bekerja sebagaimana mestinya. ${ }^{14)}$

Asas dalam pertanggungjawaban pidana adalah tiada pidana tanpa kesalahan. Pertanggungjawaban pidana dikenal juga sebagai kemampuan untuk bertanggung jawab. Ada beberapa sarjana yang mengemukakan definisi kemampuan bertanggung jawab yaitu :

Van Hamel mengatakan bahwa orang mampu bertanggung jawab itu harus memenuhi tiga syarat yaitu :

1) Mampu untuk menginsyafi makna dan akibat sungguh-sungguh dari perbuatannya sendiri;

2) Mampu untuk menginsyafi bahwa perbuatannya itu bertentangan dengan ketertiban masyarakat;

3) Mampu untuk menentukan kehendaknya terhadap perbuatan itu. ${ }^{15)}$
11) Ibid
12) Ibid, hlm. 65
13) Ibid, hlm.66
14) Barda Nawawi Arief, Diktat Kuliah Hukum Pidana, hlm. 135.
15) Ibid, hlm. 135. 
Simons mengatakan bahwa mampu bertanggung jawab adalah mampu untuk menginsyafi sifat melawan hukumnya perbuatan dan sesuai dengan keinsyafan itu mampu untuk menentukan kehendaknya. ${ }^{16)}$

Sedangkan Moeljatno mengatakan bahwa untuk adanya kemampuan bertanggung jawab harus ada :

1). Kemampuan untuk membeda-bedakan antara perbuatan yang baik dan yang buruk; yang sesuai hukum dan yang melawan hukum (faktor akal).

2). Kemampuan untuk menentukan kehendaknya menurut keinsyafan tentang baik buruknya perbuatan tadi (faktor kesadaran). ${ }^{17)}$

Orang yang tidak mampu bertanggung jawab adalah orang yang keadaan jiwa / bathinnya tidak sehat dan tidak normal karena penyakit (Pasal 44 KUHP) . Ada yang mengatakan juga bahwa kemampuan bertanggung jawab ini adalah alasan pemaaf dalam pemidanaan.

Moeljatno mengatakan bahwa tindak pidana dipisahkan dari pertanggung jawaban yang artinya kemampuan bertanggung jawab adalah unsur dari kesalahan, oleh karena itu apabila seseorang melakukan tindak pidana yang tidak dapat dipertanggungjawabkan kepadanya maka kesalahannyapun tidak ada sehingga ia tidak dapat dipidana. Dan untuk adanya kemampuan bertanggung jawab ini tidak perlu dibuktikan, oleh karena hanya apa yang disebutkan dalam rumusan tindak pidana saja yang harus dibuktikan. ${ }^{18)}$

Simons dan Van Hamel mengatakan bahwa tindak pidana itu meliputi perbuatan dan pertanggungjawaban. Artinya secara teori bahwa kemampuan bertanggung jawab itu adalah unsur dari tindak pidana, sehingga jika unsur kemampuan bertanggung jawab ini tidak ada maka tindak pidananyapun tidak ada. Tetapi Simons juga mengatakan bahwa hukum positif kemampuan bertanggung jawab tidak dipandang sebagai unsur tindak pidana melainkan suatu keadaan pribadi yang menghapuskan pidana seperti tersebut dalam Pasal 58 KUHP. ${ }^{19)}$

Tapi Pompe mengatakan " apabila pemeriksaan tentang kemampuan bertanggung jawab daripada terdakwa menghasilkan keragu-raguan maka terdakwa harus dianggap bertanggung jawab." ${ }^{20)}$

Kemampuan bertanggung jawab merupakan unsur (elemen) kesalahan, karena mestinya untuk membuktikan adanya kesalahan unsur tadi harus dibuktikan pula. Hal ini sangat sulit dan memakan banyak waktu dan ongkos. Oleh sebab itu karena pada umumnya orang-orang adalah normal bathinnya dan mampu bertanggungjawab, maka unsur ini dianggap diam-diam selalu ada, kecuali kalau ada tanda-tanda yang menunjukan bahwa terdakwa mungkin jiwanya tidak normal. Dalam hal ini hakim harus memerintahkan pemeriksaan yang khusus terhadap keadaan jiwa terdakwa tersebut selakipun tidak diminta oleh pihak terdakwa. Jika hasilnya memang jiwanya tidak normal, maka menurut Pasal 44 KUHP pidana tidak dapat dijatuhkan. Jika hasil pemeriksaan masih meragu-ragukan bagi hakim, itu berarti bahwa adanya kemampuan bertanggung jawab tidak terbukti, sehingga kesalahan tidak ada dan pidana tidak dapat dijatuhkan, berdasarkan azas "tidak dipidana jika tidak ada kesalahan".

Sebaliknya Pompe mengatakan bahwa kemampuan bertanggung jawab merupakan elemen strafbaar feit dan semata-mata menganggapnya sebagai strafuitsluitingsgrond yaitu alasan penghapusan pidana. Akibatnya ialah apabila hakim ragu-ragu apakah terdakwa dapat

\footnotetext{
16) Ibid.

17) Moeljatno, Asas-Asas Hukum Pidana,Op.Cit.,hlm. 112.

18) Ibid,hlm. 139.

19) Ibid.

20) Roeslan Saleh, KUHP dengan Penjelasannya, Yayasan penerbit Gajah Mada, Yogyakarta, hlm. 64-
}

65. 
dipertanggungjawabkan atau tidak di situ berarti bahwa perkecualian Pasal 44 KUHP tidak ada, sehingga pidana harus dijatuhkan. ${ }^{21)}$

Sedangkan Van Hammel merumuskan sebagai berikut yaitu strafbaar feit adalah kelakuan orang(menselijke gedraging) yang dirumuskan dalam wet yang bersifat melawan hukum, yang patut dipidana, dan dilakukan dengan kesalahan. ${ }^{22)}$

\section{PEMBAHASAN}

Perjudian atau permainan judi adalah tiap-tiap permainan dimana pada umumnya kemungkinan mendapat untung tergantung pada peruntungan belaka, juga karena permainannya lebih terlatih atau lebih mahir. Di situ termasuk segala pertaruhan tentang keputusan , perlombaan atau permainan lain-lainnya yang tidak diadakan antara mereka yang turut berlomba atau bermain, demikian juga segala pertaruhan lainnya.

Perjudian ini banyak bentuknya ada yang disebut dengan judi buntut, rolett, dadu, gapleh dan ada juga judi yang menebak hasil pertandingan seperti sepak bola atau balap kuda atau juga judi dengan cara lain. Seiring dengan perkembangan jaman dan kemajuan teknologi ada jenis judi baru yaitu perjudian jenis kupon togel Hongkong/King, judi jenis ini adalah judi dengan cara bermainnya dengan memasang angka-angka yang dikehendaki oleh pemasang dan apabila angkanya cocok dengan pemutarannya akan mendapat hadiah yang sudah ditentukan, judi ini berasal dari negeri China yang mana bentuknya termasuk macam judi buntut.

Polisi Republik Indonesia juga mempunyai tugas mencegah memberantas menjalarnya penyakit-penyakit masyarakat antara lain : pengemis; perjudian, pemadatan, pemabukan, perdagangan manusia, gelandangan. Tugas Polisi Republik Indonesia Negara dalam mencegah dan memberantas penyakit-penyakit masyarakat tersebut ditujukan kepada penyakit-penyakit masyarakat yang akan/telah menjadi kejahatan / pelanggaran.

Tindak Pidana yaitu suatu perbuatan yang pelakunya dapat dikenakan hukuman sedangkan perjudian itu mencari keuntungan dalam suatu permainan, sehingga perjudian dapat dikenakan sanksi pidana atau hukuman. Dari hasil penelitian ke beberapa Polsek ternyata tindak pidana perjudian itu jarang yang dilanjutkan proses pidananya dikarenakan tindak pidana perjudian adalah merupakan tindak pidana ringan. Bahkan sanksi pidana yang terdapat dalam Pasal 303 Bis yang mengancam tindak pidana perjudian dengan hukuman penjara selama 4 tahun dan dalam Pasal 303 KUHP diancam hukuman 10 tahun tetapi pasalpasal pidana tentang perjudian ini juga tidak pernah diterapkan dengan alasan bahwa tindak pidana perjudian adalah tindak pidana ringan yang tidak perlu dihukum. Padahal akibat dari adanya perjudian sebagai penyakit masyarakat akan menimbulkan akibat bagi keluarga, dan masyarakat.

Selama ini tindakan yang dilakukan oleh Polsek dan Polres di Kota Bandung adalah dengan melakukan rajia terhadap tindakan perjudian tersebut, daru sekian banyak pelaku tindak pidana perjudian yang tertangkap dalam oprasi cipta kondisi, yang akan diseret ke pengadilan hanyalah penjual atau penyedia sarana judinya sedangkan para pemainnya biasanya langsung di lepaskan dengan berbagai alasan padahal akibat dari perjudian ini sangat merusak hidup dan penghidupan manusia pada masa yang akan datang dan tentu saja kalau para penegak hukum tidak bergerak akan mengancam perkembangan generasi muda bangsa Indonesia yang merupakan tulang punggung bangsa Indonesia.

Penangkapan terhadap tersangka Anang bin alm Nana sebagai tersangka pelaku tindak pidana perjudian yaitu dengan menjadikan perjudian sebagai mata pencaharian oleh penyidik Polres Bandung adalah sudah tepat dan juga terhadap tersangka telah dilakukan penahanan selama proses penyidikan. Tetapi penerapan hukum yang dilakukan oleh penyidik

21) Moeljatno, Op.cit., hlm. 169.

22) Ibid 
Polres Bandung yaitu berupa penerapan Pasal 303 KUHP terhadap tersangka adalah kurang tepat karena seharusnya di gabungkan atau dijunctokan dengan Pasal 303 bis atau dengan UU No.7 tahun 1974 tentang Penertiban Perjudian yang ancaman hukumannya lebih berat.

Hal ini disebabkan karena perjudian merupakan perbuatan yang bertentangan dengan norma agama, moral, kesusilaan maupun hukum serta membahayakan bagi penghidupan dan kehidupan masyarakat, bangsa dan negara. Bagaimanapun juga bentuk dan macam perjudian sudah banyak beredar di masyarakat baik yang dilakukan secara terang-terangan maupun secara sembunyi-sembunyi, oleh karena itu perjudian merupakan tindak pidana yang meresahkan masyarakat.

Penangkapan dan penahanan terhadap tersangka Anang bin alm Nana oleh Polres Bandung adalah sebagai salah satu upaya untuk memberantas tindak pidana perjudian yang semakin merajalela di masyarakat, bahkan sebagian masyarakat cenderung menganggap perjudian sebagai sesuatu yang wajar dan tidak perlu dipermasalahkan lagi sehingga hal ini berakibat semakin banyak agen-agen judi togel dan judi-judi lainnya dimasyarakat yang tanpa disadari telah menyedot dana masyarakat dalam jumlah yang cukup besar.

Tindakan hukum yang dilakukan penyidik Polres Bandung terhadap pelaku tindak pidana perjudian adalah selain dengan menerapkan ketentuan Pasal 303 bis KUHP dan juga Pasal 2 UU No.7 tahun 1974 tentang Penertiban Perjudian, penyidik juga seharusnya mengamankan para pembeli atau pemasang judi togel jenis Hongkong/King tersebut sehingga menjadi contoh bagi masyarakat luas bahwa perjudian itu adalah merupakan kejahatan yang tidak hanya pengedar atau pengecer yang akan dikenakan atau dijeratsanksi pidana tetapi para pembeli atau pemasangnyapun dapat dikenakan pertanggungjawaban pidana dijerat dengan pasal mengenai perjudian.

Pemberantasan tindak pidana pejudian tidak hanya dapat dilakukan oleh Polri saja tetapi karena perjudian adalah perbuatan yang bertentangan dengan norma agama, moral, kesusilaan maupun hukum serta membahayakan bagi penghidupan dan kehidupan manusia serta mempunyai akibat negatif dan merugikan terhadap moral dan mental masyarakat terutama generasi muda, maka diperlukan adanya kerjasama dari semua aparat penegak hukum untuk memberantas tindak pidana perjudian ini. Salah satu caranya adalah dengan menjatuhkan hukuman yang berat kepada para pelaku perjudian sesuai dengan Pasal 2 UU No.7 tahun 1974 tentang Penertiban Perjudian atau juga dengan menerapkan Pasal 303 bis.

Penghukuman yang berat kepada para pelaku tindak pidana perjudian adalah merupakan salah satu bentuk upaya pemberantasan tindak pidana perjudian karena pertanggungjawaban pelaku tindak pidana perjudian tidak hanya pada saat ini, tetapi dampak dari tindak pidana perjudian ini dapat meluas yang mana dapat merusak moral dan normanorma lainnya terutama bagi genarasi muda sebagai penerus bangsa serta akibat lain dari tindak pidana perjudian adalah dalam bidang ekonomi, dimana perjudian ini akan menyebabkan munculnya tindak pidana lainnya yang dapat mengancam keamanan dan ketertiban di masyarakat.

Masalah perjudian adalah merupakan penyakit masyarakat yang membahayakan, maka perlu upaya yang sungguh-sungguh dan sistematis untuk memberantasnya tidak hanya dari pihak pemerintah dan aparat penegak hukum tetapi juga dari kesadaran hukum dan partisipasi masyarakat untuk bersama-sama dan bahu membahu menanggulangi dan memberantas semua bentuk perjudian. Dan terutama adalah perlu adanya pembaharuan terhadap KUHP terutama yang mengatur tentang tindak pidana perjudian. 


\section{KESIMPULAN}

1. Untuk memberantas perjudian, pemerintah dalam hal ini pihak Kepolisian sebagai penegak hukum seharusnya tidak hanya memproses para Bandar judinya saja tetapi juga para pemainnya agar memberikan efek jera bahwa judi itu merupakan suatu kejahatan yang akan menjadi cikal bakal terjadinya kejahatan lain

2. Kepada pemerintah juga penulis menyarankan agar selain dari tindakan hukum yang dilakukan oleh pihak kepolisian yaitu berupa sanksi pidana dalam Pasal 303 dan Pasal 303 Bis tetapi juga harus mencari alternative hukuman lain atau restoraktif justice yang dapat diterapkan pada pelaku perjudian seperti sanksi denda atau sanksi sosial yang dapat dijatuhkan pada para pelaku selain dari sanksi pidana, karena dari sisi kerugian Negara apabila semua pelaku tindak pidana di beri sanksi pidana akan merugikan Negara. Sehingga restoraktif justice adalah pilihan yang paling tepat, dan hal ini akan berimbas pada perubahan peraturan.

\section{DAFTAR PUSTAKA}

Andi Hamzah, Hukum Acara Pidana Indonesia, Arikha Media Cipta, Jakarta,1996.

Bambang Waluyo, Pidana dan Pemidanaan,Sinar Grafik,Jakarta, 2008.

Barda Nawawi Arief,Masalah Penegakan Hukum dan Kebijakan Hukum Pidana dalam Penangulangan Kejahatan,Kencana, Jakarta, 2007.

Dalil Mutiara, Tafsir KUHP, Bintang Indonesia, Jakarta, 1962.

E. Utrecht, Hukum Pidana I, Rangkaian Sari Kuliah.

Kartini Kartono, Patologi sosial, PT. Raja Grafindo Persada, Jakarta,2015.

Koriyati, Hukum Penintensier Indonesia, Bandung, 2007.

M. Hamdan, Politik Hukum Pidana, PT. Raja Grafindo Persada, Jakarta, 1997.

Moeljatno, Asas-Asas Hukum Pidana, PT. Rineka Cipta, Jakarta,1993.

............... Perbuatan Pidana dan Pertanggungan Jawab Dalam Hukum Pidana, Rineka Cipta, Jakarta, 1993.

Moch. Faisal Salam, Hukum Acara Pidana Dalam Teori Dan Praktek Mandar Maju Bandung 2001

M. Yahya Harahap, Pembahasan Permasalahan dan Penerapan KUHAP (Penyidikan dan Penuntutan), Edisi kedua,Sinar Grafika, Jakarta,2006.

M. Karjadi dan R. Soesilo, Kitab Undang-Undang Hukum Acara Pidana dengan Penjelasan Resmi dan komentar, Politeia, Bogor, 1997.

PAF Lamintang, Dasar-Dasar Hukum Pidana Indonesia, PT Citra Aditya Bhakti ,Bandung, 1997.

Romli Atsasmita,Sistem Peradilan Pidana,Perspektif Eksistensialisme dan Abolisionisme,Bina Cipta,Bandung, 1996.

Teguh Sulistia, Aria Zurnetti, Hukum Pidana Horizon Baru Pasca Reforasi, PT. Raja Grafindo Persada, Jakarta, 2011.

Wirjono Prodjodikoro, Hukum Acara Pidana di Indonesia, Sumur Bandung, Bandung, 1983. Asas-Asas Hukum Pidana di Indonesia, Refika Aditama, Bandung, 2003. 